\title{
Characterisation of a newly isolated SVCV strain in Ukraine
}

\section{Yuriy Rud ${ }^{1^{*}}$,}

\author{
Natalia Matvienko', \\ Leonid Buchatskiy ${ }^{2}$ \\ ${ }^{1}$ Institute of Fisheries \\ of the NAAS of Ukraine, \\ 135, Obukhivska St., \\ Kyiv 03164, Ukraine \\ ${ }^{2}$ Institute of Biology and Medicine, \\ Taras Shevchenko \\ National University of Kyiv, \\ 64/13, Volodymyrs'ka St., \\ Kyiv 01601, Ukraine
}

Spring Viraemia of Carp Virus (SVCV) has been well documented since the 1960s. This virus infection generally results in an acute haemorrhagic syndrome with septicaemia and associated high mortality. During a fish health inspection in carp farms in the Eastern region of Ukraine, SVCV was isolated from yearlings of the common carp Cyprinus carpio. For virus isolation and characterisation, methods of cell culture, EM, PCR, and sequencing were used. Preliminary examination of infected fish revealed a range of lesions, particularly in spleen and kidney tissues. The virus grew in fish cell lines of FHM and EPC with infectious titre of $10^{6.2-6.5}$ and $10^{6.9-7.4} \mathrm{TCID}_{50} / \mathrm{ml}$, respectively. Investigation by electron microscopy demonstrated that ultrastructurally the isolated virus was similar to rhabdoviruses. Virions were non-enveloped with a typical bullet profile, approximately 80 to $180 \mathrm{~nm}$ in length and 60 to $90 \mathrm{~nm}$ in diameter. In addition, the nucleotide sequence of the glycoprotein gene $G$ fragment in size of 579 base pairs was analysed. The nucleotide sequence was registered at GenBank under the accession number MH043331. The phylogenetic analysis revealed a close relationship of East Ukrainian isolates of SVCV with sequences that represent the strains from genogroup Ib.

Keywords: SVCV, common carp, molecular identification

\section{INTRODUCTION}

Spring viraemia of carp (SVC) is a viral disease caused by Spring viraemia of carp virus (SVCV)

\footnotetext{
*Corresponding author. Email: rudziknew@ukr.net
}

or Carp sprivivirus, which is classified as a member of the family Rhabdoviridae belonging to the genus Sprivivirus (ICTV, 2018 Virus Taxonomy: 2018 Release). The genome of SVCV is a linear single-stranded negative RNA molecule that encodes five structural proteins: nucleoprotein 
$(\mathrm{N})$, phosphoprotein $(\mathrm{P})$, matrix protein $(\mathrm{M})$, glycoprotein (G), and viral RNA-dependent RNA polymerase (L) in the order: $39-\mathrm{N}-\mathrm{P}-\mathrm{M}$ G-L-59 (Ahne et al., 2002).

The World Organization for Animal Health classified SVC as an especially dangerous disease of cultured fish (OIE, 2000). SVCV is distributed worldwide (Ashraf et al., 2016; Woo, Bruno, 2011). SVCV is an economically important fish pathogen since cyprinids are the main aquacultured species in Ukraine. The annual carp yield of stocked species amounts to 20,000 tons. In Ukraine, carp mortality caused by SVCV (mainly that of fingerlings) usually amounts to $30-40 \%$, but sometimes can reach up to $70 \%$ (Matvienko et al., 2014).

Today, molecular epidemiology is instrumental for the investigation and control of the disease due to its ability to reveal the possible sources of infection. The molecular characterization of a viral pathogen allows to trace phylogenetic relationships of the virus and to determine its evolutionary history. Therefore, the aims of our study were to investigate SVCV from carp species reared in Eastern Ukraine using molecular approaches. In this study, we present the results of PCR and nucleotide sequence analysis as well as cell culture detection and electron microscopy studies of the East-Ukrainian isolates of SVCV sampled from carps from March to June in 2017 and 2018.

\section{MATERIALS AND METHODS}

Sample collection. During spring periods of 2017 and 2018, a total of 40 fish samples were continuously collected from alive and moribund carp fingerlings in fish farms ((1) "Chervona Dolyna" and (2) "SlavaTES", Slavyansk district; (3) "Oleksandrivka" and (4) "Mayachka", Oleksandrivka district; (5) "Nitrius" and (6) "Krasnolymanske", Lymansk district) of PC "Donrybkombinat" in Donetsk region. The capacity of PC "Donrybkombinat" is 5000 ha with of up to 2800 tons of annual fish production. The samples that displayed key lesions or signs of disease were considered for laboratory testing. At least five fish with symp- toms of disease from each affected pond or cage were collected and placed into a separate submission form for each site. The samples of internal organs (kidney and spleen) were removed from individual fish and placed into a $1.5 \mathrm{ml}$ microcentrifuge tube. Samples were transported to the laboratory on ice and processed immediately.

Cell lines. All collected samples were tested using cell culture assay. FHM and EPC cell lines were maintained in MEM medium (PAA) supplemented with $100 \mathrm{U} \mathrm{ml}^{-1}$ penicillin, $100 \mu \mathrm{g} \mathrm{ml}^{-1}$ streptomycin and $10 \%$ foetal bovine serum (FBS Gold, PAA). The samples of internal organs were homogenized with MEM and filtered through the $0.45 \mu \mathrm{m}$ membrane (Sarstedt). Then the virus suspension was inoculated onto 24-hours cell monolayer growing in $25 \mathrm{~cm}^{2}$ flasks. After absorption for $60 \mathrm{~min}$ at $20^{\circ} \mathrm{C}$, MEM medium supplemented with $2 \%$ of FBS was added to cells. When a complete viral cytopathic effect (CPE) was evident, the tissue culture supernatant was harvested and centrifuged at $2500 \times \mathrm{g}$ for $10 \mathrm{~min}$ at $4^{\circ} \mathrm{C}$ to remove cell debris. The $50 \%$ tissue culture infective dose $\left(\mathrm{TCID}_{50} \mathrm{ml}^{-1}\right)$ of the resulting supernatant was determined (Dougherty, 1964).

Virus purification. The virus was purified from tissue culture supernatant by the method of ultracentrifugation. Briefly, after cell debris was separated by centrifugation at $2500 \times g$ for $10 \mathrm{~min}$ at $4^{\circ} \mathrm{C}$, the pellet was discarded and the supernatant was centrifuged in Beckman L5-50B in a rotor of SW-40 for $60 \mathrm{~min}$ at $70500 \times g$ at $4^{\circ} \mathrm{C}$. The virus pellet was suspended in TNE (50 mM Tris- $\mathrm{HCl}, 150 \mathrm{mM}$ $\mathrm{NaCl}, 1 \mathrm{mM}$ EDTA, $\mathrm{pH}$ 7.5) and centrifuged at $2500 \times g$ for $5 \mathrm{~min}$ at $4^{\circ} \mathrm{C}$. Then the virus suspension was used for electron-microscopy investigation and viral RNA extraction. For electron-microscopy investigation, the viral suspension was stained with $2 \%$ uranyl acetate (Chen et al., 2009).

RNA extraction and cDNA synthesis. Genomic viral RNA was extracted using GeneJET $^{\mathrm{TM}}$ RNA Purification Kit (ThermoScientific) as described in manufacturer's protocol. The cDNA synthesis was conducted using 
RevertAid $^{\mathrm{TM}}$ Premium First Strand cDNA Synthesis Kit (ThermoScientific).

$R T-P C R$. In order to compare different approaches for virus identification, the reverse transcription PCR (RT-PCR) was used to analyse all collected samples. Amplification of a714bpfragmentofSVCV cDNA wasperformed using primers derived from sequences of the region coding for the glycoprotein gene: 5'-TCT-TGG-AGC-CAA-ATA-GCT-CARRTC-3' (SVCV F1) and 5'-AGA-TGG-TATGGA-CCC-CAA-TAC-ATH-ACN-CAY-3' SVCV R2). If the CPE in cell culture was not extensive, the second round of amplification was used. We used the semi-nested assay to amplify 606 bp fragment using primers: SVCV F1 and SVC R4 with the following sequence 5'-CTG-GGG-TTT-CCN-CCT-CAAAGY-TGY-3' (Stone et al., 2003). The PCR mixture consisted of $12,5 \mu \mathrm{l}$ of DreamTaq Green PCR MasterMix (ThermoScientific), 20 pmol of each primer, $1 \mu \mathrm{l}$ of cDNA and the nuclease-free water up to a total volume of $25 \mu$ l. The amplification was conducted with 35 temperature cycles of: 1 minute at $95^{\circ} \mathrm{C}$, 1 minute at $55^{\circ} \mathrm{C}$ and 1 minute at $72^{\circ} \mathrm{C}$ followed by a final extension step of 10 minutes at $72^{\circ} \mathrm{C}$. The PCR products were analyzed by $2.0 \%$ agarose gel electrophoresis.

Sequence analysis. The PCR products were purified with the Silica Bead DNA Gel Extraction Kit (ThermoScientific) and subjected to nucleotide sequence analysis using a $3130 \mathrm{Ge}$ netic Analyzer (Applied Biosystems). The sequences were aligned with available SVCV sequences in the GenBank database (NCBI) according to the CLUSTAL $\mathrm{W}$ by the software of Molecular Evolutionary Genetics Analysis (MEGA) v. 6.0. The nucleotide sequence was registered in GenBank under accession number of MH043331.

\section{RESULTS}

Clinical signs. All moribund and dead carps were on the surface of fish tanks while the samples were being screened. External signs of moribund fish included uncoordinated spi- ral swimming and violent flexing of the body. The diseased fish were notably darker in colour and appeared weak and lethargic. Acute infection was systemic, and the haemorrhages in different organs could be recognized. Liver, kidney, and digestive tract lesions were noted. Clinical symptoms of the disease included muscle lesions, gill oedema, deformation of internal organs, and tissue necrosis.

The level of mortality on the fish farms of PC "Donrybkombinat" was reported in a number of different ways. Two different figures for each farm reflected the monthly and the cumulative mortality (Table 1). Monthly mortality was calculated as the percentage of fish lost on a farm within March-June. It was measured for assessing the health of the fish on the each farm. The cumulative mortality over a full production cycle was the percentage of fish lost on a whole facility of each farm of PC "Donrybkombinat" during the entire period, given as a percentage of the total number of fish that were initially stocked on the farm. It was reported once the entire farm has been fully harvested after a epizooty. The cumulative mortality in inspected fish farms was 45$55 \%$ on the average (Table 1).

Virus reproduction in cell culture. The reproduction of the isolated virus in fish continuous cell cultures of FHM and EPC was investigated. These cell lines were sensitive to virus. The virus caused morphological changes and cells rounding. Subsequently cells scaled from the surface and CPE of virus on cells was visible. For FHM the complete destruction of monolayer was noted at 4-5 days after infection (d.a.i.). For EPC cells the $\mathrm{CPE}$ and complete destruction of cell monolayer were marked at 3-4 d.a.i. Infectious titres of SVCV isolates for cell lines FHM and EPC were 10 $0^{6.2-6.5}$ and $10^{6.9-7.4} \mathrm{TCID}_{50} / \mathrm{ml}$ respectively. The highest infectious titre was observed for EPC cells, which is appropriate as this cell line was derived from the common carp - a natural SVCV host. That is why the EPC is the most appropriate cell lines for SVCV diagnostic.

TEM. The results of our electronic-microscopy investigations of purified viral particles 
Table 1 . The monthly and cumulative mortality (\%) of carp Cyprinus carpio caused by SVCV in fish farms of PC "Donrybkombinat" during March-June 2017 and 2018

\begin{tabular}{c|ccccccccccc}
\hline \multirow{2}{*}{ Fish farm $^{*}$} & \multicolumn{7}{|c|}{$\mathbf{2 0 1 7}$} & \multicolumn{3}{c}{$\mathbf{2 0 1 8}$} \\
\cline { 2 - 10 } & March & April & May & June & CM $^{*}$ & March & April & May & June & CM \\
\hline 1 & 5.0 & 19.0 & 21.0 & 4.0 & 50.0 & 6.0 & 23.0 & 25.0 & 8.0 & 62.0 \\
2 & 6.5 & 20.2 & 23.0 & 5.0 & 54.7 & 7.0 & 23.0 & 24.0 & 6.0 & 60.0 \\
3 & 3.0 & 16.0 & 23.0 & 8.0 & 50.0 & 4.5 & 16.5 & 23.0 & 7.0 & 51.0 \\
4 & 5.5 & 18.0 & 22.5 & 7.5 & 53.0 & 6.0 & 18.4 & 22.0 & 8.0 & 54.4 \\
5 & 8.0 & 13.0 & 14.0 & 3.0 & 38.0 & 7.0 & 14.0 & 14.0 & 5.0 & 40.0 \\
6 & 8.0 & 15.5 & 13.0 & 4.0 & 40.5 & 19.0 & 20.5 & 23.0 & 4.0 & 66.5 \\
\hline \multicolumn{7}{c}{ Total per period } & & $\mathbf{4 7 . 7 0}$ & \multicolumn{7}{c}{ Total per period } & $\mathbf{5 5 . 6 5}$ \\
\hline
\end{tabular}

* Fish farms: (1) "Chervona Dolyna” and (2) "SlavaTES”, Slavyansk district; (3) "Oleksandrivka” and (4) "Mayachka", Oleksandrivka district; (5) "Nitrius" and (6) "Krasnolymanske", Lymansk district;

** CM - cumulative mortality;

${ }^{* * *}$ The average water temperature during the period is $+12^{\circ} \mathrm{C}\left(+2^{\circ} \mathrm{C}\right.$ in March and $+22^{\circ} \mathrm{C}$ in June $)$;

${ }^{* * * *}$ Fish density was 100,000 fingerlings/ha (each fish is $50-100 \mathrm{~g}$ in size).

revealed basic characteristics for rhabdoviruses morphology and ultrastructure. The virions were non-enveloped with a typical bullet profile, approximately 80 to $180 \mathrm{~nm}$ in length and 60 to $90 \mathrm{~nm}$ in diameter.

Phylogenetic analysis. The size of RT-PCR products after the first round of amplification was $714 \mathrm{bp}$. The total number of samples was 40 and only five (5) of them were positive after the first round for SVCV using seminested RT-PCR. Mainly, more positive SVCV samples were detected by means of $606 \mathrm{bp}$ fragments. The total amount of SVCV positive probes proved by semi-nested PCR was 27 . It should be noted that after the first round of PCR, not all products were visible on agarose gels. To avoid this, we used the semi-nested assay using the second round and increased sensitivity of PCR. Only six RT-PCR positives samples were sequenced with reason to cover one sample for each facility. All samples shared the same nucleotide sequences. The results of sequencing showed that amplified PCR products were identical to fragments of SVCV glycoprotein gene $\mathrm{G}$ deposited in GenBank by other researchers. The nucleotide sequence was registered in GenBank under the acces- sion number of MH043331. East-Ukrainian $2 \mathrm{Ukr} 2017$ isolate showed a high level of nucleotide sequence diversity ( $82.7 \%$ to $99 \%$ identity) among other SVCV isolates. The highest identity of $99.0 \%$ was noted for the sequence of glycoprotein G in SVCV isolate 2/90 (accession number AJ538060) isolated in Moldova (Stone et al., 2003). Both isolates represent the $\mathrm{Ib}$ genogroup. Interestingly, amino acid sequences of $2 \mathrm{Ukr} 2017$ and 2/90 isolates were $100 \%$ identical.

The identity between Ukrainian 2Ukr2017 and $1 \mathrm{Ukr} 2014$ (accession number MH043330) SVCV isolates was $92.6 \%$ and $94.3 \%$ in nucleotide and amino acid sequences, respectively. The phylogenetic analysis revealed a close relationship 1Ukr2014 with SVCV isolates that represent the Fijan strain and genogroup Id, which is traditionally associated with SVC in Europe (Figure). However, the 2Ukr2017 isolate was more similar to the strains previously isolated in Ukraine, Moldova, and Russia in the late eighties; also, it has less homology with the virus isolate $1 \mathrm{Ukr} 2014$. Therefore, it could be assumed that the origin of the East-Ukrainian isolate differs from the one described for 1Ukr2014 (Table 2). 


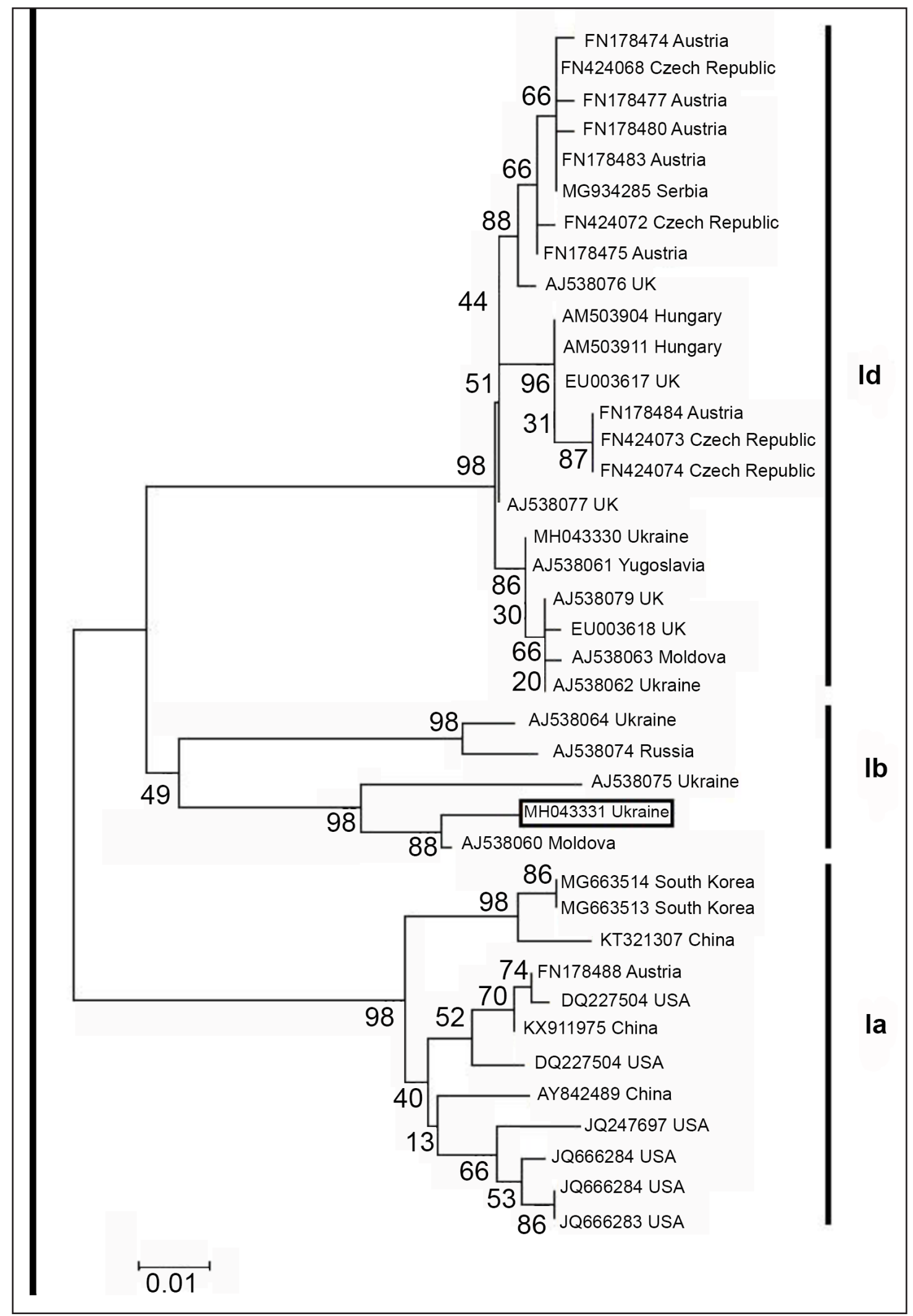

Figure. Phylogenetic analysis of G gene fragment of the new Ukrainian isolate of SVCV (accession number MH043331). The tree was generated by means of a neighbour-joining algorithm in MEGA software v. 6.0 (bootstrap 1000) 
Table 2. Isolates of SVCV and G gene sequence data analysed

\begin{tabular}{|c|c|c|c|c|c|}
\hline Isolate name & Host name & $\begin{array}{l}\text { Year of } \\
\text { isolation }\end{array}$ & $\begin{array}{c}\text { Country of isola- } \\
\text { tion }\end{array}$ & $\begin{array}{l}\text { Geno- } \\
\text { group }\end{array}$ & $\begin{array}{l}\text { Accession num- } \\
\text { ber }\end{array}$ \\
\hline N3-14 & Bighead carp & 1986 & Ukraine & Id & AJ538062 \\
\hline N1-5 & Grass carp & 1986 & Ukraine & $\mathrm{Ib}$ & AJ538064 \\
\hline RHV & Rainbow trout & 1989 & Ukraine & $\mathrm{Ib}$ & AJ538075 \\
\hline 1_Ukr & Common carp & 2014 & Ukraine & Id & MH043330 \\
\hline 2_Ukr & Common carp & $2017 / 2018$ & Ukraine & $\mathrm{Ib}$ & MH043331 \\
\hline $\mathrm{P} 4$ & Common carp & 1983 & Russia & $\mathrm{Ib}$ & AJ538074 \\
\hline M2-76 & Common carp & 2007 & Moldova & & EF593136 \\
\hline M2-78 & Hypophthamichthys molitrix & 1983 & Moldova & Id & AJ538063 \\
\hline $2 / 90$ & Common carp & 1990 & Moldova & $\mathrm{Ib}$ & AJ538060 \\
\hline $17312 / 5$ & Common carp & 1981 & Hungary & Id & AM503904 \\
\hline $17417 / 3$ & Sheatfish & 1981 & Hungary & Id & AM503911 \\
\hline S30 & Common carp & 1971 & Yugoslavia & Id & AJ538061 \\
\hline $\mathrm{DE} / 1999$ & Common carp & 1999 & Serbia & Id & MG934285 \\
\hline $\mathrm{SO} / 2001$ & Common carp & 2001 & Serbia & & MG934280 \\
\hline PI05 & Pike & 2009 & Czech Republic & Id & FN424068 \\
\hline V-636 & Carp koi & 2009 & Czech Republic & Id & FN424073 \\
\hline V-637 & Siberian sturgeon & 2009 & Czech Republic & Id & FN424074 \\
\hline $\mathrm{V}-632$ & Common carp & 2009 & Czech Republic & Id & FN424072 \\
\hline $66-94$ & Common bream & 1994 & Austria & Id & FN178474 \\
\hline $92-94$ & Carp koi & 1994 & Austria & Ia & FN178475 \\
\hline $39-97$ & Common carp & 1997 & Austria & Id & FN178477 \\
\hline $122-02$ & Goldfish & 2000 & Austria & Id & FN178480 \\
\hline $37-06$ & Carp koi & 2006 & Austria & Id & FN178483 \\
\hline $38-06$ & Common carp & 2006 & Austria & Id & FN178484 \\
\hline 3911-07 & Common carp & 2007 & Austria & $\mathrm{Ia}$ & FN178488 \\
\hline 970395 & Common carp & 1997 & UK & Id & AJ538076 \\
\hline 940626 & Tench & 1994 & UK & Id & EU003617 \\
\hline 880062 & Common carp & 1988 & UK & Id & AJ538079 \\
\hline 770346 & Common carp & 1977 & UK & Id & AJ538077 \\
\hline 880163 & Common carp & 1988 & UK & Id & EU003618 \\
\hline 212364 & Carp koi & 2002 & USA & $\mathrm{Ia}$ & DQ227501 \\
\hline 322383 & Carp koi i & 2004 & USA & Ia & DQ227504 \\
\hline 500549 & Common carp & 2007 & USA & $\mathrm{Ia}$ & JQ666282 \\
\hline $566087-1$ & Largemouth bass & 2008 & USA & $\mathrm{Ia}$ & JQ666283 \\
\hline $566087-2$ & Bluegill & 2008 & USA & Ia & JQ666284 \\
\hline MN/27923/11 & Common carp & 2011 & USA & Ia & JQ247697 \\
\hline 992 & Common carp & 2004 & China & Ia & AY842489 \\
\hline SH150514 & Goldfish & 2015 & China & $\mathrm{Ia}$ & KT321307 \\
\hline Shlj3 & Common carp & $2015 / 2016$ & China & Ia & KX911975 \\
\hline SH150518 & Carp koi & 2015 & China & $\mathrm{Ia}$ & KT321308 \\
\hline ADC-SVC2016-1 & Common carp & 2016 & South Korea & $\mathrm{Ia}$ & MG663514 \\
\hline ADC-SVC2016-3 & Largemouth bass & 2016 & South Korea & Ia & MG663513 \\
\hline
\end{tabular}




\section{DISCUSSION}

In this report we described the isolation of SVCV from carp C. carpio fingerlings in fish farms of PC "Donrybkombinat" that is located in Donetsk region. Several SVCV isolates were described in Ukraine during 1986, 2006 and the period of 2013-2014 (Stone et al., 2003; Miller et al., 2007; Matvienko et al., 2014). In almost all cases they were isolated in the southern, western, and central parts of Ukraine. Based on the comparison of previous Ukrainian and current European SVCV isolates we suggest that East-Ukrainian SVCV 2 Ukr2017 relates to Fijan strain but is quite distinct from isolate 1Ukr2014 (Stone et al., 2013; Padhi \& Verghese, 2012). SVCV isolate 2Ukr2017 belongs to the $\mathrm{Ib}$ genogroup of viruses isolated in Ukraine, Moldova, and Russia, while $1 \mathrm{Ukr} 2014$ isolate is closer to European strains of the Id genogroup.

Ukrainian isolates were assigned to Genogroup I and were primarily isolated from the common carp; however, viruses assigned to this group were also isolated from another fish species such as the silver carp, the bighead carp, and the grass carp. It should be noted that in comparison of two Ukrainian isolates, the case of branch separating and evidence that SVCV has probably evolved independently in different areas. On the other hand, the $2 \mathrm{Ukr} 2017$ isolate could represent a virus strain from the former post-Soviet countries that existed or were brought to Donetsk region across the wide area.

An interesting point would be a thorough phylogenetic analysis of the isolates. According to recent publications, SVCV isolates are classified into four genogroups, Ia, Ib, Ic, and Id. Genogroup Ia contains isolates from Asia (Zhang et al., 2009; Kim et al., 2018) and the Americas, while isolates from Eastern Europe mainly belong to genogroups $\mathrm{Ib}$ and $\mathrm{Id}$ (Basic et al., 2009; Padhi, Verghese, 2012). Most likely, the 2Ukr2017 isolate was brought from Russia or even Moldova, because south and east regions are on the border and the cooperation between fish farms is very significant. This could be a novel finding and should therefore be confirmed by analysis of all East Ukrainian strains. Another important fact is that there veterinary control over the transboundary fish movement in Ukraine is insufficient.

During SVC epizootics, virus concentrations in the water may reach levels which are more than sufficient to infect fish. Up to $10^{5}$ TCID/ $\mathrm{ml}^{-1}$ were detected in troughs with carp fingerlings during an epizootic. A number of papers describe the stability of the virus in the environment (Hoffmann et al., 2002; Bandin, Dopazo, 2011). Therefore, rapid and accurate diagnosis of SVCV infection is critical to the control of the virus because carp surviving infections as juveniles may become life-long carriers and shed live virus.

The screening of samples using RT-PCR would potentially be more sensitive than tissue culture; however, suitable cell lines also can be used for surveillance of cyprinids for SVCV. Additionally, molecular techniques are required in the identification of the serotype and genotype of the isolated SVCV-strains. Since the virus is horizontally transmitted, the detection of the virus in broodstock, even in the absence of the disease, often means the destruction of fish population. There will be a need to screen not only all farmed populations of carp in the eastern regions of Ukraine, but also to confirm the presence of SVCV in wild populations of common carp Cyprinus carpio or another cyprinids species.

The general geographical distribution of SCVC strains is known. The Fijan strain was mainly identified in Europe (Fijan et al., 1971), but another SVCV strains occur in most of major cyprinid-farming countries in Asia, South Africa, and Americas (Dikkeboom et al., 2004). The virus is shed mostly with the faeces and urine of clinically infected fish and by carriers. Waterborne transmission is believed to be the primary route of infection, but bloodsucking parasites like leeches and the carp louse may serve as mechanical vectors of SVCV. Ukrainian carp farms closely collaborate with each other and fish-farms of the neighbouring countries; consequently, it might be one of the putative ways of spreading the SVCV to/from Ukraine. 
Therefore, we suggest that the movement of fish to different countries should be stopped, since this movement increases the risk of spreading the virus and causes new disease outbreaks in new geographical areas.

In this research, the SVCV was identified in Donetsk region indicating a wide spread of the virus in Eastern Ukraine. The RT-PCR assay and nucleotide sequence analysis confirmed the prevalence of isolated virus to the Fijan strain of SVCV. In our opinion, a semi-nested PCR assay should be used for rapid virus identification, because in the case of a low concentration of target RNA only this molecular approach was capable to identify the virus. The complete monitoring of SVCV and its diagnostic in cyprinids cultivated in fish farms or native ponds of Ukraine will result in total data of virus distribution and identification of other strains widespread in Europe.

\section{ACKNOWLEDGEMENTS}

We thank Dr Inessa Skripkina from the Institute of Molecular Biology and Genetics of NASU for her assistance in sequencing.

Received 10 April 2019

Accepted 17 September 2019

\section{References}

1. Ahne W, Bjorklund HV, Essbauer S, Fijan N, Kurath G, Winton JR. Spring viremia of carp (SVC). Dis Aquat Org. 2002; 52: 261-72.

2. Ashraf U, Lu Y, Lin L, Yuan J, Wang M, Liu X. Spring viraemia of carp virus: recent advances. J Gen Virol. 2016; 97: 1037-51.

3. Bandin I, Dopazo CP. Host range, host specificity and hypothesized host shift events among viruses of lower vertebrates. Vet Res. 2011; 42: 67.

4. Basic A, Schachner O, Bilic I, Hess M. Phylogenetic analysis of spring viraemia of carp virus isolates from Austria indicates the exis- tence of at least two subgroups within genogroup Id. Dis Aquat Org. 2009; 85: 31-40.

5. Chen HL, Liu H, Liu ZX, He JQ, Gao LY, Shi XJ, Jiang YL. Characterization of the complete genome sequence of pike fry rhabdovirus. Arch Virol. 2009; 154: 1489-94.

6. Dikkeboom A, Radi C, Toohey-Kurth K, Marcquenski S. First report of Spring Viremia of Carp Virus (SVCV) in wild Common Carp in North America. J Aquat Anim Health. 2004; 16: 169-78.

7. Dougherty R. Animal virus titration techniques. In Harris JC (ed.), Techniques in experimental biology. New York, NY: Academic Press, Inc; 1964. p. 183-6.

8. Fijan N, Petrinec Z, Sulimanović O, Zwillenberg LO. Isolation of the viral causative agent from the acute form of infectious dropsy of carp. Vet Arh. 1971; 41: 125-38.

9. Hoffmann B, Schutz H, Mettenleiter T. Determination of the complete genomic sequence and analysis of the gene products of the virus of spring viremia of carp, a fish rhabdovirus. Virus Res. 2002; 84: 89-100.

10. International Committee on Taxonomy of Viruses (ICTV). Genus: Sprivivirus in Virus Taxonomy: 2018 Release. EC 50, Washington, DC, July 2018. https://talk.ictvonline.org/

11. Kim MJ, Lee S, Godahewa GI, Hwang JY, Seo JS, Hwang SD, Lee J. Complete genome sequence and phylogenetic analysis of spring viremia of carp virus isolated from leather carp (Cyprinus carpio nudus) in Korea in 2016. Arch Virol. 2018; 163(10): 2917-9.

12. Matvienko N, Rud Yu, Buchatsky L. Partial nucleotide sequences of glycoprotein gene of Ukrainian strain of Spring viraemia of carp virus. Zoology and Ecology. 2014; 24(1): 70-4.

13. Miller O, Fuller FJ, Gebreyes WA, Lewbart GA, Shchelkunov IS, Shivappa RB, Joiner C, Woolford G, Stone DM, Dixon PF, Raley ME, Levine JF. Phylogenetic analysis of spring virema of carp virus reveals distinct subgroups with common origins for recent isolates in 
North America and the UK. Dis Aquat Organ. 2007; 76(3): 193-204.

14. Office International des Épizooties (OIE). Spring viremia of carp. In: Diagnostic manual for aquatic animal diseases. 3rd ed. Paris: Office International des Épizooties; 2000. p. 46-52.

15. Padhi A, Verghese B. Molecular evolutionary and epidemiological dynamics of a highly pathogenic fish rhabdovirus, the spring viremia of carp virus (SVCV). Vet Microbiol. 2012; 156: 54-63.

16. Stone D, Ahne W, Denham K, Dixon P, Liu C. Nucleotide sequence analysis of the glycoprotein gene of putative Spring Viraemia of Carp Virus and Pike Fry Rhabdovirus isolates reveals four genogroups. Dis Aquat Org. 2003; 53: 203-10.

17. Stone DM, Kerr RC, Hughes M, Radford AD, Darby AC. Characterisation of the genomes of four putative vesiculoviruses: tench rhabdovirus, grass carp rhabdovirus, perch rhabdovirus and eel rhabdovirus European X. Arch Virol. 2013; 158(11): 2371-7.

18. Woo PTK, Bruno DW (Ed.). Fish diseases and disorders: 3. Viral, bacterial and fungal infections. 2nd. Edition. CAB International: Oxfordshire, 2011, $930 \mathrm{pp}$.

19. Zhang NZ, Zhang LF, Jiang YN, Zhang T, Xia C. Molecular Analysis of Spring Viraemia of Carp Virus in China: A Fatal Aquatic Viral Disease that Might Spread in East Asian. PLoS ONE. 2009; 4(7): e6337.
Yuriy Rud, Natalia Matvienko, Leonid Buchatskiy

\section{NAUJAI IŠSKIRTI KARPIŲ PAVASARINĖS VIREMIJOS VIRUSO TIPAI UKRAINOJE}

\section{Santrauka}

Karpių pavasarinès viremijos viruso diagnozè pradèta fiksuoti nuo XX a. 7 dešimtmečio. Šis virusas paprastai sukelia ūminị hemoraginị sindromą ir septicemiją, o tai lemia didelị mirštamumą. Patikrinus žuvų būklę rytinio Ukrainos regiono karpių fermose, karpių pavasarinès viremijos virusas buvo išskirtas iš paprastųjų karpių (Cyprinus carpio). Viruso išskyrimui ir apibūdinimui buvo naudojamos ląstelių kultūros, EM, PGR ir sekvenavimas. Preliminariai ištyrus užkrèstas žuvis, nustatyta daugybė pažeidimų, ypač blužnies ir inkstų audiniuose. Virusas išaugo FHM ir EPC žuvų ląstelių linijose, jų infekcinis titras buvo atitinkamai $10^{6,2-6,5}$ ir $10^{6,9-7,4} \mathrm{TCID}_{50} / \mathrm{ml}$. Elektroninès mikroskopijos tyrimas rodo, kad išskirtas virusas struktūriškai panašus ị rabdovirusus. Virionai neturèjo apvalkalo su tipišku kulkos profiliu, jų ilgis apie $80-180 \mathrm{~nm}$, skersmuo 60-90 nm. Išanalizuota 579 bazių porų ilgio glikoproteinų $G$ geno fragmento nukleotidų seka. Nukleotidų seka buvo užregistruota "GenBank“ (registracijos numeris MH043331). Filogenetinè sekų analizè atskleidè glaudų Rytų Ukrainos karpių pavasarinès viremijos viruso izoliatų ryšį su Ib geno grupès tipo sekomis.

Raktažodžiai: karpių pavasarinès viremijos virusas, paprastasis karpis, molekulinè identifikacija 